\title{
A király, a zsarnok és a propaganda. Mátyás király és a 15. századi Drakula-történetek [The King, and The Tyrant and the Propaganda. King Mathias and the Fifteenth Century Stories about Dracula]. By Levente Nagy.
}

Budapest: Szépirodalmi Figyelő Alapítvány, 2021, 214 pp.

\section{Ildikó Hajdu}

Eötvös Loránd University, Faculty of Humanities, Institute of Literary and Cultural Studies, 1088 Budapest, Múzeum körút 4/A; ildi.h301@gmail.com

Levente Nagy - a prominent expert of Hungarian-Romanian cultural relations-has published in recent years several books on subjects as diverse as the reception of the works of Nicholas Zrínyi in seventeenth century Transylvania, ${ }^{1}$ the presence of Hungarians and Romanians in the works of Luigi Ferdinando Marsigli, ${ }^{2}$ the mythical genealogies of the Hunyadi, Vlad Dracul and Esterházy families, ${ }^{3}$ and the origins and spreading of the Protestant Reform among the Romanians of Transylvania in the early modern period. ${ }^{4}$

In his most recent monograph, entitled The King, the Tyrant and the Propaganda. King Matthias and the Dracula Narratives in the $15^{\text {th }}$ century, he further explores the historical and historiographical traditions around Vlad III (alias Dracula), Prince of Wallachia, which started to circulate about him in the second half of the fifteenth century. His proverbial ruthlessness and cruelty gained him a name among the most vicious historical figures already during his lifetime. The aim of the latest monograph of Nagy is unconventionally ambitious: it seeks to revisit and refute the so called "propaganda theory", according to which these rumours are nothing but tools of a well-prepared defamatory campaign. As claimed by the elaborators and circulators of the "propaganda theory" (Ș. Papacostea, G. Giraudo, M. Cazacu, J. Bérenger, R. R. Florescu, R. T. McNally-mainly historians of Romanian origin in the second half

Nagy, Zrínyi és Erdély.

2 Nagy, Határok, vándorok, kémek.

3 Nagy, A holló, a gyürü és a sárkány jegyében.

4 Nagy, Lehetséges küldetés; Nagy, A román reformáció; Nagy, Reforma la români. 
of the 20th century) the publications of these malicious stories about Dracula were part of a "smear campaign" against the Count which was ordered by the Hungarian king, Matthias Corvinus (Matthias I or Hunyadi Mátyás). Matthias-according to the "propaganda theory"-would have embezzled the financial support of forty thousand ducats which the Pope had originally sent to the King with the objective that Matthias should aid Vlad III, the Voivode of Wallachia in the militarisation of the area against the menacing Ottoman Empire. Instead, in 1462, Matthias captured Vlad, and held him in captivity for ten years. Following this theory, Matthias would have tried to justify his dishonourable deeds to the Vatican by spreading rumours of Dracula's cruelty and treason with the help of these malevolent propagandistic publications. If this was true, it would make Matthias one of the first political figures who recognised the manipulative potential of the printing press.

Levente Nagy seeks to examine and re-contextualize-according to new, previously neglected aspects - the corpus of the early forms of Dracula myth, and to define their connection to each other, as well as to earlier literary traditions and topoi. Nagy's book therefore sets out an approach of ideological criticism on two levels: on the one hand, Nagy criticizes the propagandistic interpretation of the myth of Dracula in current academic discourse (in order to unveil the ideological character of the now conventional image and interpretation of Dracula). On the other hand, he also attempts to unfold the actual "ideological" (political, propagandistic, or manipulative) motivations behind the stories of Dracula in the sources (nearly) contemporaneous with the Count.

At the end of the preface, Nagy claims regarding his objective that "[i]n my present work I do not intend to find out the historical truth. I am a lot more interested in the mechanisms of myth formation. ${ }^{5}$ Nevertheless, this statement sometimes contradicts his own argument, because-fortunately enough-it often seems that Nagy seeks to reconstruct some kind of "historical truth" (though, of course, only as much as it is allowed by the lack or inconsistency of his sources). One could find the greatest merits and results of this book in these attempts, as it is obvious that the "historical truth" as a background is also indispensable: it serves as a point of reference, in relation to which "the mechanisms of myth formation" could be analysed and the myth could be interpreted as purported fiction. Nagy clearly and convincingly refutes the propaganda-focused explanation of the creation of the Dracula-myth which counts as consensually accepted in contemporary literary and historical studies.

According to Nagy, the most problematic feature of the "propaganda theory" is its anachronism: the supporters of the theory hastily employ the preconceptions of the twentieth century to interpret the historical circumstances of the fifteenth century. ${ }^{6}$

5 Translation mine: Nagy, A király, a zsarnok és a propaganda, 10.

6 "At first glance, there is only one problem with this well-structured and apparently coherent theory: it tastes too much like the twentieth century." Translation mine: Nagy, A király, a zsarnok és a propaganda, 19. 
The monograph refutes almost every element of this theory: one cannot verify with historical evidence neither the act of the embezzlement, nor the hostile relationship between Matthias and Dracula. Moreover, Nagy suggests that the imprisonment (or "house arrest") of the Voivode by Matthias was rather an escape for Dracula than a punishment: the boyars of Wallachia revolted against him and threatened his life. Furthermore, the German language publications of the stories about Dracula which started to spread chiefly from Vienna in 1460s would not have been useful to convince the Vatican about the Voivode's cruelty because of their language and their limited circulation. The humanist circle around Matthias also shared a generally positive (or at least ambivalent) image of Dracula, and this ambivalence definitely does not seem to be compatible with the supposed propagandistic, defamatory objectives of Matthias. Moreover, Matthias could have no reason to launch this "smear campaign" against the Voivode while the King arranged two marriages from his own family to Dracula. According to the analysis of Nagy, one may conclude that there might have been an implicit intention behind the elaboration of the "propaganda theory", which could be regarded as a manifestation of twentieth century medievalism: the figure of Dracula was whitewashed and re-interpreted in an apologetic way in order to be presented as a victim and a martyr. Therefore, his character could be exploited to strengthen the nationalist tendencies in Romanian historiography from the second half of the twentieth century onwards. In contrast, Nagy chooses a completely new perspective to explain the roots of the stories about Dracula by examining the contemporary, fifteenth century reception of the narratives. Nagy claims that the stories about Dracula belonged to the popular culture already in the fifteenth century, and the incunable prints from Vienna (and later on from other German merchant towns as Nuremberg, Lübeck, Augsburg and Strasbourg) - which presented the most cruel and vicious image of Dracula - were produced in order to entertain and also to morally educate the wider reading public of Vienna, and later on of several other towns in Western Europe. However, Nagy could have drawn a further conclusion at this point in his analysis and-similarly to the scholarship on the modern revival of Dracula narratives - could have examined this issue from a postcolonial perspective. The "Western" interest in the Voivode could be linked to the Central European stereotypes about the peripheral regions of Europe. From a Central European perspective, Wallachia could have seemed an exotic, half-barbaric territory located on the frontier of the known and the unknown world.

Consequently, the reflections of Nagy on his aim to examine the mechanisms of myth formation instead of finding historical truth rather imply a shift of focus than a complete neglect of factual historiography. Compared to the "traditional" methods of historical research, Nagy modifies the method of the analysis, the arrangement of the sources and data, and takes into account the theoretical achievements of the linguistic and the cultural turn. His monograph does not only seek to publish all the 
relevant primary data and sources about its subject, but also to compare the various stories and narratives of these events. Thus, Nagy examines a more abstract level of reality which differs from what is conventionally called "historical truth". Following his critical approach, it is not only possible to learn more about "history" (in the sense what had happened exactly), but also about the evolution and interaction of these historical narratives.

These two approaches are intertwined already in the first half of the book: we are introduced to the different and ambiguous interpretations of the figure of Dracula, and Nagy subsequently seeks to determine a historical reality behind the narratives of these events, as he discusses what the reasons of the captivation of Dracula were, and how it exactly occurred. In the second half of the monograph, the literary analysis and the investigation of myth formation becomes predominant. This shift of focus is justified by the author's conclusion that the intention of the Dracula stories was far from representing the reality. Moreover, the sources of these fifteenth century narratives do not originate from the narrowly interpreted historical "reality", but from the literary topoi and motifs of the Middle Ages and the Renaissance, in accordance with Nagy's theory that these stories were fabricated in order to entertain the citizens of Vienna. Nagy discovers several literary connections and outright influences between the stories of the Voivode and the Biblical narratives of the Old and New Testament, or medieval legends of saints (e. g. the stories of Saint Andrew and of the crucifixion of Saint Peter head downward in the Legenda Aurea), collections of short stories (e. g. the Cento novelle antiche o Libro di novelle e di bel parlar gentile) and ancient and early medieval historical sources (e. g. Tacitus, Livy, Tertullianus, and Iordanes). However, the analysis of Nagy is not confined to sources of literary fiction and historical works, but includes the representations of the Dracula legend in the fine arts, as well. This makes his argumentation even more convincing, as in the case when Nagy examines the blending of the figures of Dracula and Pilate: ${ }^{8}$ the textual and visual sources strengthen and justify each other. The message is clear in every case: Pilate and Dracula both betrayed Christ, who represents Christianity, and they became a pagan, or Turkish ally, respectively.

The only important point of criticism one could raise is that the monograph does not reflect on its own status in the vast field of the academic discourse on the literary and artistic interpretation of the figure of Dracula, that could described with the terms of "ideological criticism", "deconstructivism" and to a certain degree also with "reception aesthetics." Nagy does not unravel the background of his approach in philosophy, literary theory and historiography which defines the extensive and versatile critical

8 Cp. Meister des Marienlebens, Crucifixion, altar picture, 1465, Wallraf-Richartz Museum, Cologne; Lucas Cranach, Crucifixion, c. 1515-1520, Städelsches Kunstinstitut und Städtische Galerie, Frankfurt; Anonymous Master, Christ in front of Pilate, altar picture, Narodna Galerija, inv. no. NG S 1176, Ljubljana. 
arsenal of the monograph. Still perhaps the greatest merit of Nagy's monograph is its transdisciplinary approach. One could hardly pinpoint if it belongs to the field of literary or historical studies: its methods and sources are drawn from both disciplines. Due to its well-written style and comprehensible structure, the book remains accessible to a wider circle of readers, that is obviously dependent on its subject, too, which has been able to entertain the public for more than five hundred years.

\section{Literature}

Garcia, Anca Andriescu. "Dracula - Hybridity and Metafiction." Acta Universitatis Sapientiae - Philologica 10 (2018): 53-74. doi.org/10.2478/ausp-2018-0004

Nagy, Levente. Zrínyi és Erdély [Zrínyi and Transylvania]. Budapest: Argumentum Kiadó, 2003.

Nagy Levente. Határok, vándorok, kémek. A magyarokról és a románokról alkotott kép Luigi Ferdinando Marsili írásaiban [Frontiers, Wanderers, Spies. The Image of Hungarians and Romanians in the Writings of Luigi Ferdinando Marsili]. Budapest: Lucidus, 2011.

Nagy, Levente. Lehetséges küldetés? Hitek és tévhitek a román reformáció körül [Mission possible? Myths of the Romanian Protestant Reform]. Budapest: ELTE Eötvös Kiadó, 2013.

Nagy, Levente. A holló, a gyürü és a sárkány jegyében. Magyar, lengyel és román Corvinusok Drakulától Esterházy Pálig [In the sign of the Crow, the Ring and the Dragon. Hungarian, Polish and Romanian Corvinus families from Dracula to Pál Esterházy]. Budapest: ELTE Eötvös Kiadó, 2014.

Nagy, Levente. A román reformáció. Egy 16-17. századi magyar-román kulturális és irodalmi transzferjelenség [The Romanian Protestant Reform. A HungarianRomanian Cultural and Literary Transfer in the 16th and 17th Centuries]. Budapest: Ráció, 2020.

Nagy, Levente. Reforma la români. Un fenomen de transfer cultural în secolele XVIXVII [The Romanian Protestant Reform. A Cultural Transfer in the 16th and 17th Centuries]. Oradea : Ratio et Revelatio, 2021.

Nagy, Levente. A király, a zsarnok és a propaganda. Mátyás király és a 15. századi Drakula-történetek [The King, the Tyrant and the Propaganda. King Matthias and the Dracula Narratives in the 15th Century]. Budapest: Szépirodalmi Figyelő Alapítvány, 2021.

(c) 2021 The Author(s).

This is an open-access article distributed under the terms of the Creative Commons Attribution-Non Commercial 4.0 International Licence (CC BY-NC 4.0). 